Woziwoda B. 2006b. Różnorodność florystyczna różnowiekowych lasów izolowanych w krajobrazie rolniczym Polski Środkowej, a problem zachowania i ochrony rodzimych gatunków leśnych. - Studia

i Materiały Centrum Edukacji Przyrodniczo-Leśnej w Rogowie 11: 103-109.

WozIwoda B. 2006c. Inwentaryzacja flory roślin naczyniowych w lasach Nadleśnictwa Poddębice (RDLP Łódź). - Studia i Materiały Centrum Edukacji Przyrodniczo-Leśnej w Rogowie 14: 115-125.

Woziwoda B. 2007. Flora lasu szadkowskiego. - Biuletyn Szadkowski 7: 185-195.

Woziwoda B. 2009. Morphological diversity of ferns in the Dryopteris affinis group in Central Poland. - W: E. SzCZÉ́́́nIAK \& E. Gola (red.), Genus Dryopteris Adans. in Poland, s. 45-59. Polish Botanical Society, Institute of Plant Biology, University of Wrocław, Wrocław.

Woziwoda B. 2010. Dryopteris affinis (Dryopteridaceae) in Polish lowlands. - W: Z. MiReK \& A. NIKEL (red.), Rare, relict and endangered plants and fungi in Poland, s. 137-147. W. Szafer Institute of Botany, Polish Academy of Sciences, Kraków.

ZAJĄC A. \& ZAJĄC M. (red.). 2001. Atlas rozmieszczenia roślin naczyniowych w Polsce. s. xii + 714. Nakładem Pracowni Chorologii Komputerowej Instytutu Botaniki Uniwersytetu Jagiellońskiego, Kraków.

ZAJĄC A. 1978. Założenia metodyczne „Atlasu rozmieszczenia roślin naczyniowych w Polsce”. - Wiadomości Botaniczne 22(3): 145-155.

ZarZycki W., Wilczek Z., Woźnica P., Folcik Ł., LeWAndowska A. \& GanCAReK M. 2015. Wpływ dębu czerwonego Quercus rubra L. na populacje paproci w różnych typach fitocenoz leśnych. - Sylwan 159(8): 658-665.

Dariusz TlaŁka (autor korespondencyjny), Os. nad Soła 4/19, 32-650, Kęty, Polska; e-mail: tlalkadariusz@gmail.com

Marek Podsiedlik, Zbiory Przyrodnicze, Wydziat Biologii, Uniwersytet im. Adama Mickiewicza w Poznaniu, ul. Uniwersytetu Poznańskiego 6, 61-614, Poznań, Polska; e-mail: podsiedlikmarek@amu.edu.pl

Wptynęto: 01.01.2020 r.; przyjęto do druku: 15.12.2020 r.

DOI: https://doi.org/10.35535/ffgp-2020-0041

\title{
Rozmieszczenie, zasoby oraz zagrożenia Arenaria graminifolia (Caryophyllaceae) w Kampinoskim Parku Narodowym
}

Arenaria graminifolia Schrad. (syn. Arenaria procera Spreng., Arenaria stenophylla Ledeb., Eremogone saxatilis (L.) Ikonn.), piaskowiec trawiasty, ma rozległy zasięg, ciągnący się od rzeki Wisły w Europie Centralnej po rzekę Lenę w Azji (Meusel i in. 1965; Plantarium 2021). Jest zaliczany do elementu holarktycznego, podelementu eurosyberyjskiego (ZAJĄC \& ZAJĄC 2009).

Arenaria graminifolia w Rosji został zamieszczony w regionalnych ,czerwonych księgach” gatunków, m.in.: Udmurt (Tuganaev 2001), regionu Wołga (SEnAtor i in. 2009), obwodu Wołogodzkiego (SuSLOVA i in. 2013), okręgu Khanty-Mansiysk (VASIN 2003) oraz okręgu Vladimir (SEREGIN 2012). Europejskie populacje zagrożone wymarciem lub bliskie tego statusu stwierdzono w Austrii (FISCHER i in. 2008), na Słowacji (ELIÁš i in. 2015), 
na Węgrzech (KIRÁLy 2007), w Polsce (JAKubOwsKA-GABARA 2014), na Litwie (RAŠOMAVIČIUS 2007) oraz w Estonii (KuLL i in. 2002).

W Polsce Arenaria graminifolia osiąga zachodnią granicę zasięgu (MEUSEL i in. 1965; JALAS \& SUOMINEN 1988) i dotychczas stwierdzony był na 29 stanowiskach, koncentrujących się głównie w północno-wschodniej części kraju (JAKUBOwSKA-GABARA 2014). Z uwagi na fakt, że duża część stanowisk odnotowanych w XIX i XX w. ma charakter historyczny, piaskowiec trawiasty został uznany za gatunek krytycznie zagrożony (CR) (JAKUBOWSKA-GABARA 2014; KAŹMIERCZAKOWA i in. 2016).

Dane o fitocenozach w których występuje Arenaria graminifolia w Polsce są fragmentaryczne i ograniczają się do kilku stanowisk. Gatunek notowany był w ubogich fitocenozach leśnych reprezentujących bory świeże Peucedano-Pinetum, Leucobryo-Pinetum lub, tak jak w rezerwacie „Kulka” (woj. warmińsko-mazurskie), na murawie napiaskowej (JAKUBOWSKA-GABARA 2014).

W Kampinoskim Parku Narodowym piaskowiec trawiasty po raz pierwszy został znaleziony przez R. Kobendzę w 1930 r. na wydmach pod Krzywą Górą: ,jest to stanowisko liczne, lecz ograniczone do jednej wydmy" (KoBENDZA 1930). Drugie stanowisko zostało znalezione przez T. Humięcką w 1980 r. na Łużowej Górze: ,jedno niewielkie stanowisko" (HuMIĘCKA 1980). W związku z tym, że stanowiska te nie zostały potwierdzone na początku XXI w., A. graminifolia został uznany za takson wymarły na tym obszarze (GŁOWACKI \& Ferchmin 2003; JAKubowsKa-Gabara 2014).

Celem pracy jest przedstawienie aktualnego rozmieszczenia, warunków występowania, wielkości zasobów i zagrożeń stanowisk Arenaria graminifolia w Kampinoskim Parku Narodowym.

Niniejsza praca została oparta na materiałach zebranych w trakcie badań florystycznych, prowadzonych w latach 2005-2018 na terenie Kampinoskiego Parku Narodowego. Dane zostały uzupełnione o informacje pochodzące z literatury (KoBENDZA 1930; GŁOWACKI \& FERCHMIN 2003) oraz materiały niepublikowane (HumiĘCKA 1980), które zweryfikowano. Lokalizację stanowisk w terenie określono za pomocą odbiornika GPS i przypisano do kwadratów ATPOL o wymiarach $1 \times 1$ km (KoMSTA 2016; Verey 2017). Na stanowiskach określono liczbę pędów generatywnych, wegetatywnych oraz udokumentowano skład gatunkowy fitocenoz. Listę gatunków charakterystycznych dla syntaksonów różnej rangi oraz interpretację przynależności syntaksonomicznej oparto na opracowaniu MATUSZKIEWICZA (2013). Wiek drzewostanu podano według Operatu Ochrony EkOsystemów LEŚNYCH KPN (2002)..

Stanowiska uporządkowano według lokalizacji, od najdalej wysuniętego na wschód w kierunku zachodnim, podano kolejno: numer porządkowy, nazwę stanowiska oraz numer kwadratu ATPOL o wymiarach $1 \times 1 \mathrm{~km}$. Ponadto podano informacje o zasobach populacji oraz zbiorowisku roślinnym w którym występuje Arenaria graminifolia. Dla każdego stanowiska zamieszczono zdjęcie fitosocjologiczne.

W trakcie prowadzonych prac florystycznych w Kampinoskim Parku Narodowym, stwierdzono występowanie Arenaria graminifolia na czterech nowych stanowiskach, znajdujących się w uroczyskach Łuże, Biała Góra, Krukowa Góra oraz Czerwińskie Góry. Mimo prowadzonych intensywnych poszukiwań nie udało się potwierdzić 
stanowisk z Krzywej Góry (KoBEndza 1930) oraz Łużowej Góry (HumiĘCKA 1980) (Ryc. 1).

1. Łuże, ED1536. Stanowisko znalezione w 2005 r., znajduje się na niewielkiej wydmie od północy graniczącej z Łużową Górą, a od południa ze zdegradowanym torfowiskiem niskim. Populacja Arenaria graminifolia znajduje się na południowym, łagodnym stoku niewysokiej wydmy. Rośnie w borze sosnowym świeżym Peucedano-Pinetum (Ryc. 2), z drzewostanem w wieku około 50 lat. Jest to prawdopodobnie siedlisko boru mieszanego Querco roboris-Pinetum, zdegenerowanego wskutek inwazji Padus serotina. Szczegółową charakterystykę przedstawia zdjęcie fitosocjologiczne nr 1 (Tab. 1).

W chwili znalezienia odnotowano sześć płatów, o łącznej liczbie 3500 pędów wegetatywnych oraz 70 generatywnych. W tym samym roku podjęto próbę usunięcia z runa Padus serotina na powierzchni $50 \mathrm{~m}^{2}$ poprzez wyrywanie siewek i ścinanie większych osobników. W 2007 r. populacja Arenaria graminifolia nie uległa znaczącym zmianom, odnotowano 6 płatów o liczbie 3510 pędów wegetatywnych 3510 oraz 56 generatywnych. Wiosną 2008 roku stwierdzono, że w obrębie stanowiska, wykonane zostały cięcia w drzewostanie o charakterze trzebieży, która zwiększyła dopływ światła do runa, ale także przyczyniła się do mechanicznego uszkodzenia roślin. W obrębie 6 płatów liczba pędów wegetatywnych znacznie spadła i wynosiła 1590, a pędów generatywnych nie znaleziono. W 2009 r. odnotowano również 1590 pędów wegetatywnych oraz stwierdzono cztery pędy generatywne. Ponadto kontynuowano działania podjęte w 2005 r. w celu utrzymania luki bez występowania Padus serotina na powierzchni $50 \mathrm{~m}^{2}$. W 2011 r. populacja A. graminifolia

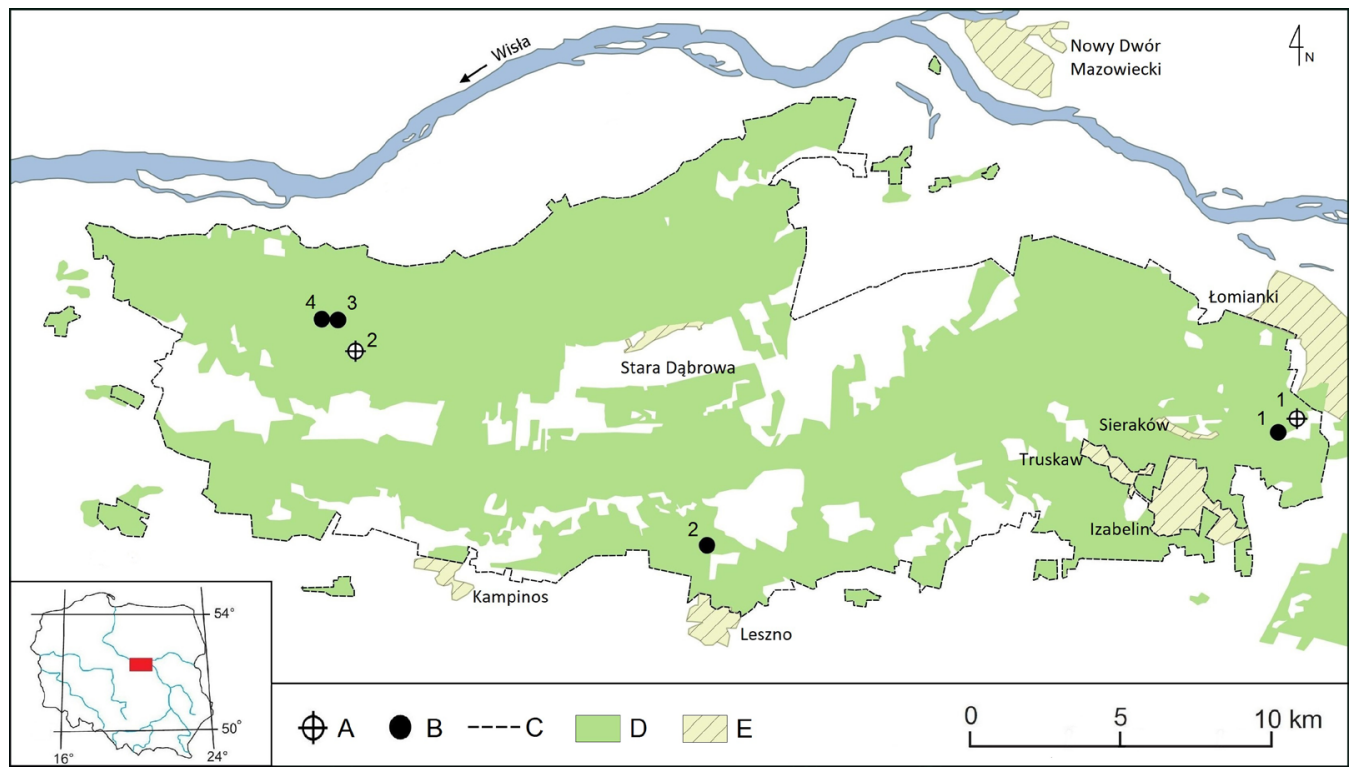

Ryc. 1. Rozmieszczenie Arenaria graminifolia na terenie Kampinoskiego Parku Narodowego: A - stanowiska historyczne, B - stanowiska aktualne, C - granica parku narodowego, D - lasy, E - zabudowania

Fig. 1. Distribution of Arenaria graminifolia in Kampinos National Park: A - historical localities, B - current localities, $\mathrm{C}$ - park borders, D - forest, E - buildings 


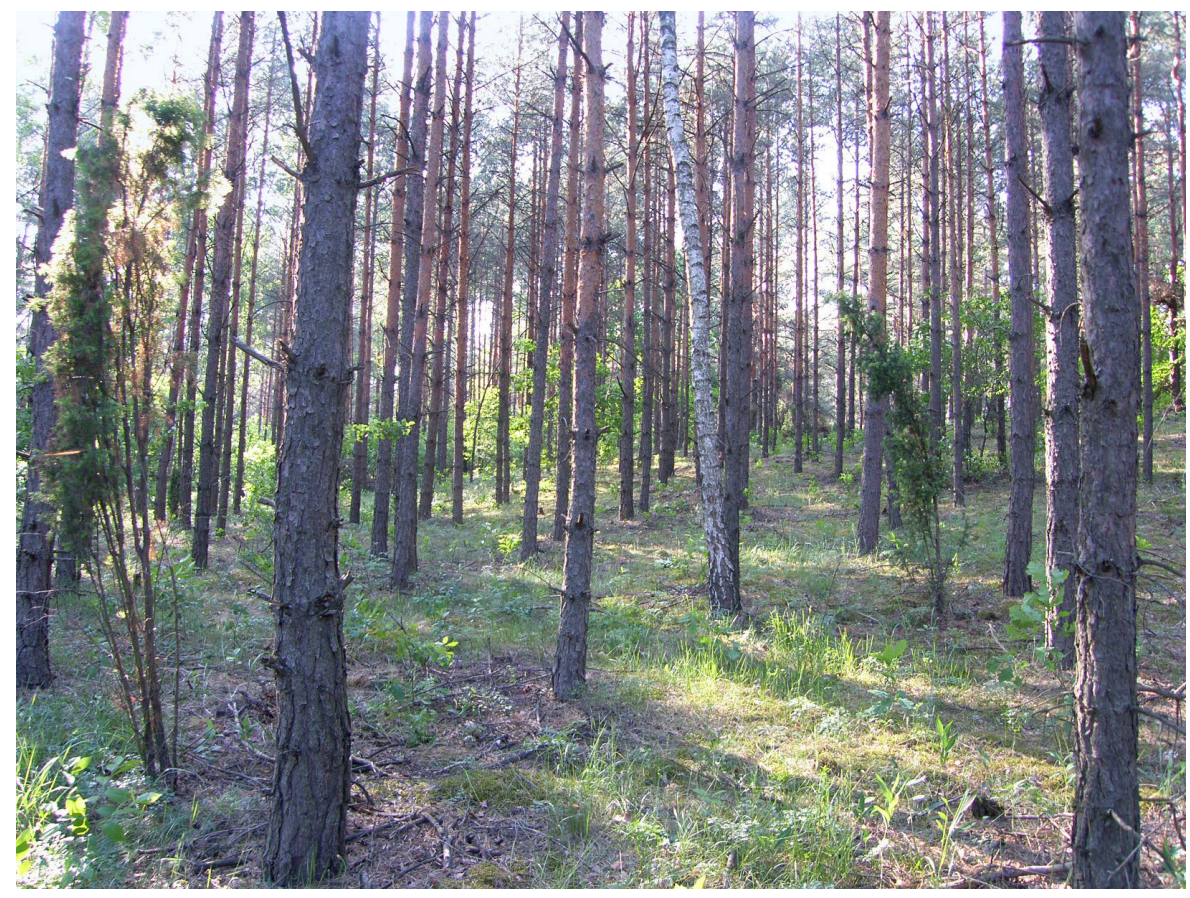

Ryc. 2. Typowe miejsce występowania Arenaria graminifolia na badanym terenie (fot. K. Torzewski)

Fig. 2. Typical site of occurrence of Arenaria graminifolia in the studied area (photo by K. Torzewski)

odbudowała się do stanu 2270 pędów wegetatywnych oraz 10 generatywnych. Również w kolejnych latach w 2013 r. oraz 2014 r. kontynuowano zabieg usuwania siewek i odrośli $P$. serotina na powierzchni $50 \mathrm{~m}^{2}$. Po roku 2014, poza potwierdzaniem obecności populacji, badań szczegółowych nie prowadzono, zaprzestano również usuwania gatunków inwazyjnych z powierzchni.

2. Biała Góra, ED1378. Stanowisko odkryte w 2014 r., znajduje się w borze na wschodnim stoku czoła wydmy zwanej Białą Górą, od wschodu graniczącej z niewielkim torfowiskiem przejściowym z klasy Scheuchzerio-Caricetea. Podczas odnalezienia odnotowano 3 płaty, o liczbie 420 pędów wegetatywnych, pędów generatywnych nie obserwowano. W 2018 r. zaobserwowano pojedyncze pędy generatywne. Populacja Arenaria graminifolia zajmuje południowo-wschodnią wystawę wydmy porośniętej drzewostanem sosnowym w wieku ok. 70 lat. Płaty piaskowca znajdują się w sąsiedztwie luki w drzewostanie. Zbiorowisko roślinne można scharakteryzować jako bór sosnowy świeży Peucedano-Pinetum. Szczegółową dokumentację fitosocjologiczną przedstawia zdjęcie nr 2 (Tab. 1).

3. Krukowa Góra, ED1205. Stanowisko znalezione w 2005 r., zlokalizowane jest u podnóża wydmy zwanej Krukową Górą, na stoku o wystawie wschodniej. W trakcie odnalezienia odnotowano 7 płatów o liczbie 2540 pędów wegetatywnych oraz 75 generatywnych. W 2011 r. odnotowano tylko 6 płatów, w obrębie których łączna liczba pędów wegetatywnych wyniosła 1180, pędów generatywnych nie zaobserwowano. Arenaria graminifolia rosła w zbiorowisku boru mieszanego Querco roboris-Pinetum, z drzewostanem w wieku 
Tabela 1. Arenaria graminifolia w zbiorowiskach roślinnych Kampinoskiego Parku Narodowego

Table 1. Arenaria graminifolia in the plant communities in Kampinos National Park

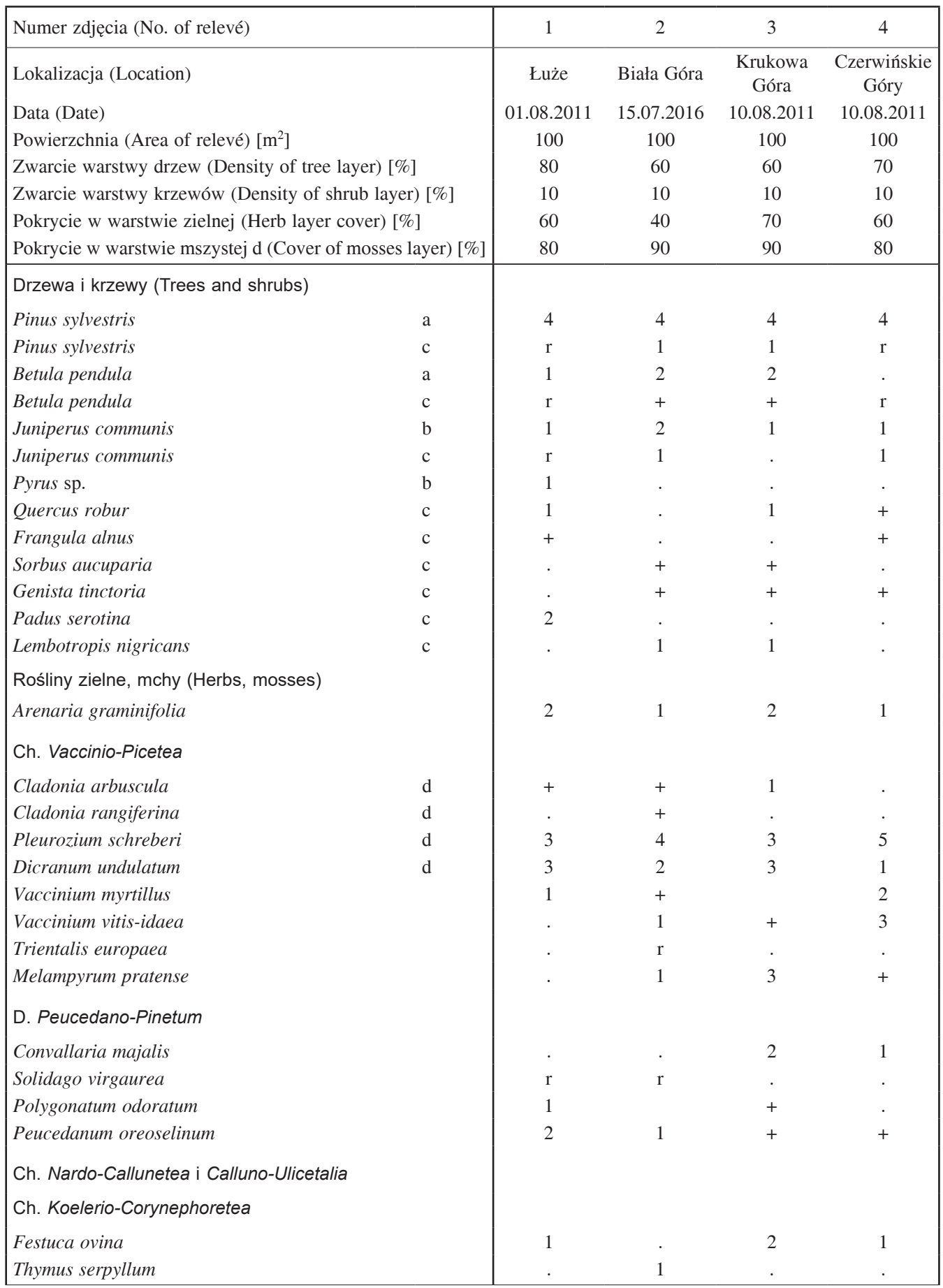


Tabela 1. Kontynuacja - Table 1. Continued

\begin{tabular}{|l|cccc|}
\hline Numer zdjęcia (No. of relevé) & 1 & 2 & 3 & 4 \\
\hline Rumex acetosella & $\mathrm{r}$ &. &. &. \\
Gypsophila fastigiata & & 1 & 1 &. \\
Vincetoxicum hirundinaria & + &. & 2 &. \\
Inne (Others) & & & & \\
Calamagrostis epigejos & 1 & & 3 & \\
Agrostis capillaris & 2 & + & 2 & 1 \\
Linaria vulgaris &. &. & 1 &. \\
Galeopsis bifida &. &. & $\mathrm{r}$ &. \\
Viola sp. & $\mathrm{r}$ &. & 1 &. \\
Anthoxanthum odoratum &. &. & + &. \\
\hline
\end{tabular}

powyżej 60 lat, przy drodze łączącej Nowiny z Famułkami Królewskimi. Szczegółową charakterystykę zbiorowiska roślinnego przedstawia zdjęcie fitosocjologiczne nr 3 (Tab. 1).

4. Czerwińskie Góry, ED1205. Stanowisko znalezione w 2011 r. zlokalizowane jest w kompleksie wydm Czerwińskie Góry. Odnotowano tu 17 płatów o łącznej liczbie 1450 pędów wegetatywnych oraz 80 generatywnych, w rozproszeniu na powierzchni ok. 1 ha. Populacja zajmuje wschodnie oraz południowe stoki wydm, w ok. 70-letnich drzewostanach sosnowych. Zbiorowisko roślinne zajmowane przez piaskowca trawiastego można określić jako uboga postać Peucedano-Pinetum, którego skład florystyczny przedstawia zdjęcie fitosocjologiczne $\mathrm{nr} 4$ (Tab. 1).

Na terenie Kampinoskiego Parku Narodowego stwierdzono dotychczas sześć stanowisk Arenaria graminifolia, z czego dwa mają charakter historyczny. Stanowiska współczesne są oddalone od siebie od kilkuset metrów do kilkunastu kilometrów (licząc w linii prostej) i wynoszą: Czerwińskie Góry - Krukowa Góra (650 m), Krukowa Góra - Biała Góra $(14,5 \mathrm{~km})$, Biała Góra - Łuże (19,1 km). Poza terenem badań najbliższe stanowisko gatunku znajdowało się ok. 15 km od stanowiska Czerwińskie Góry na zachód w okolicach Młodzieszyna (GŁOWACKi 1984), jednak badania terenowe prowadzone w 2007 r. nie potwierdziły go. Stanowisko Łuże, położone we wschodniej części Parku, znajduje się w pobliżu stanowiska odkrytego przez HuMIĘCKA (1980). Z opisu i zamieszczonego w tej pracy schematu wynika, że A. graminifolia występował na zboczu Łużowej Góry, ok. 700 m na północnywschód od współczesnego stanowiska (Ryc. 1). Dwa stanowiska znalezione w zachodniej części Kampinoskiego Parku Narodowego, tj. Krukowa Góra i Czerwińskie Góry, znajdują się w pobliżu stanowiska podanego przez Kobendze (1930) ponad 80 lat temu. Autor ten wymienia wydmy pod Krzywą Górą, co wskazuje na obszary położone na wschód od nowo odnalezionych stanowisk.

Arenaria graminifolia w Kampinoskim Parku Narodowym, podobnie jak na innych stanowiskach w kraju (Jakubowska-Gabara 2014), rośnie w widnych borach sosnowych, na podłożu piaszczystym. Stanowiska w Puszczy Kampinoskiej znajdują się zwykle na południowych stokach wydm o nieznacznym nachyleniu. Arenaria graminifolia rośnie w borach sosnowych ze związku Dicrano-Pinion, które można określić jako subkontynentalny bór świeży Peucedano-Pinetum (Tab. 1). Oprócz znacznego udziału gatunków 
charakterystycznych dla klasy Vaccinio-Piceetea, wyraźny jest również udział gatunków z klasy Koelerio-Corynephoretea oraz Nardo-Callunetea. Bory te charakteryzują się słabo wykształconą warstwą podszytu (pokrycie 10\%), w którego składzie gatunkowym dominuje Juniperus communis. Jedynie na stanowisku w Łużu jest obserwowana ekspansja Padus serotina. Sa to młode lasy w wieku od 50. do 70. lat, podczas gdy w Puszczy Kampinoskiej znaczny udział mają starodrzewia. Preferowanie przez A. graminifolia zbiorowisk
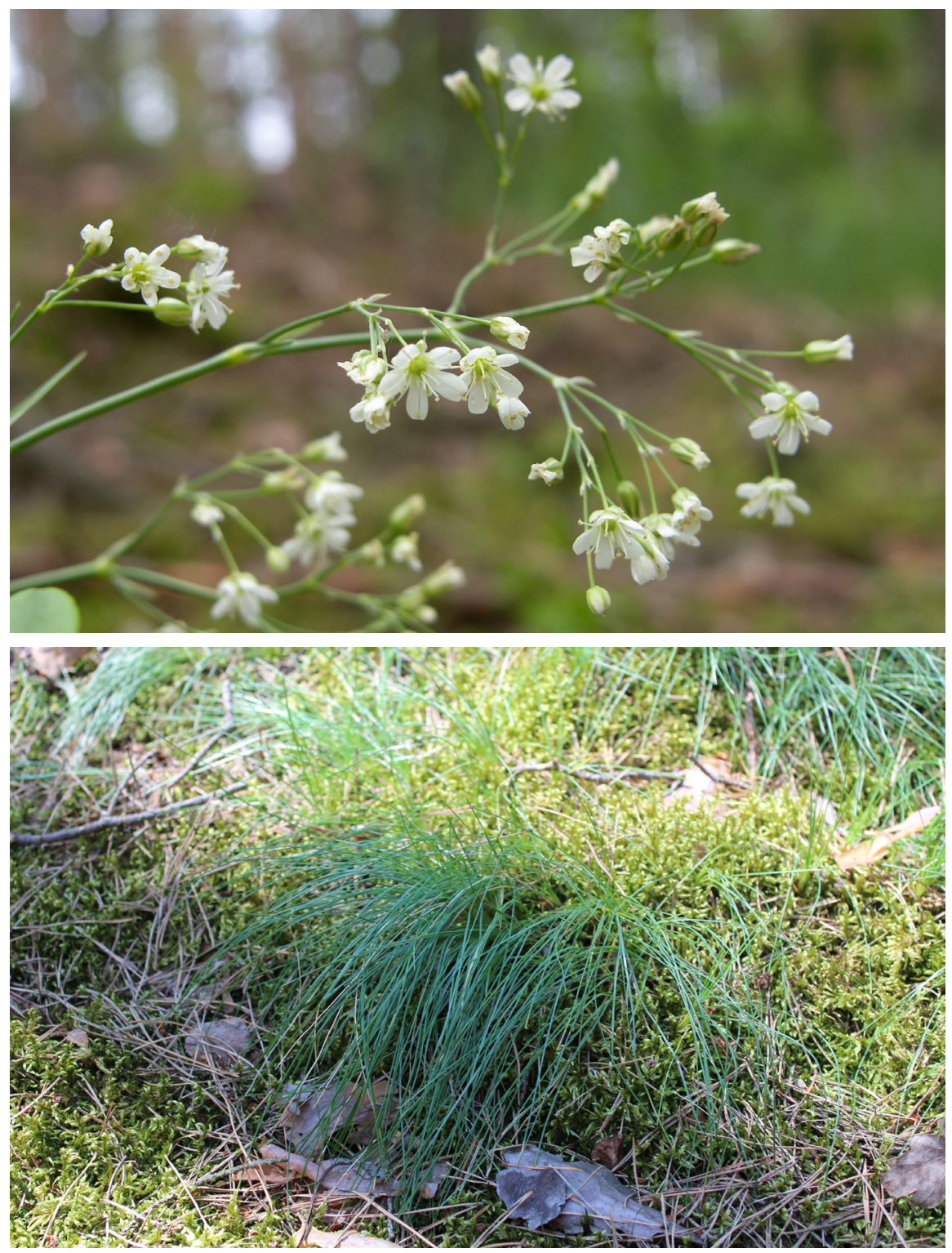

Ryc. 3. Arenaria graminifolia (fot. K. Torzewski)

Fig. 3. Arenaria graminifolia (photo by K. Torzewski) 
z młodszymi drzewostanami może być spowodowane obecnością cieńszej warstwy ściółki nakładowej niż w ponad stuletnich borach sosnowych.

Poszczególne populacje Arenaria graminifolia cechują się znacznym zróżnicowaniem liczebności pędów wegetatywnych, od kilkuset (Biała Góra) do ponad trzech tysięcy w uroczysku Łuże. Osobniki generatywne stanowiły maksymalnie 5\% populacji.

W Kampinoskim Parku Narodowym Arenaria graminifolia jest obecnie gatunkiem zagrożonym. Podstawowe zagrożenia związane są z rozproszeniem stanowisk w powiązaniu z ryzykiem wystapienia czynników losowych oraz z pogarszaniem się warunków siedliskowych, głównie wskutek zacieniania lub inwazji gatunków obcych. Potencjalne $\mathrm{i}$ istniejące zagrożenia związane są z pracami leśnymi (wszystkie stanowiska), nielegalnym ruchem pojazdów mechanicznych, a w mniejszym stopniu z ruchem pieszych (Łuże) oraz sukcesją biocenotyczną. W ostatnim przypadku szczególnie groźne są inwazje gatunków obcego pochodzenia, takich jak Padus serotina, Robinia pseudoacacia, Quercus rubra oraz ekspansja Calamagrostis epigejos. Czynna ochrona stanowisk A. graminifolia powinna się skupiać na przeciwdziałaniu zarastaniu i wzrostowi zacienienia, powodujących ograniczenie kwitnienia i owocowania (JAKUBOWSKA-GABARA 2012). W przypadku stanowiska Łuże należy kontynuować zwalczanie $P$. serotina. Należy także kontynuować monitoring na stanowiskach Krukowa Góra i Łuże, który rozpoczęto w 2011 r. w ramach działalności statutowej parku.

Stwierdzone na obszarze Kampinoskiego Parku Narodowego cztery nowe stanowiska Arenaria graminifolia liczą łącznie 5310 pędów i tym samym jest to znacząca populacja w skali kraju, skupiona w obrębie jednego obszaru chronionego. Należy jednak brać pod uwagę fakt, że stosunkowo rzadkie notowania piaskowca trawiastego mogą być spowodowane niepozornym wyglądem i trudnością w identyfikacji gatunku, ponieważ jego pędy wegetatywne przypominają trawy (Ryc. 3). Kwestia rozmieszczenia A. graminifolia w Polsce wymaga dalszych szczegółowych badań.

Summary. Arenaria graminifolia (Caryophyllaceae) in Kampinos National Park - distribution, resources and threats. Field studies conducted in 2005-2018 yielded information about the distribution and condition of Arenaria graminifolia (Caryophyllaceae) in Kampinos National Park (central Poland). Arenaria graminifolia was found at four new sites located in Łuże, Biała Góra, Krukowa Góra and Czerwińskie Góry. Historical stations from Krzywa Góra and Łużowa Góra were not reconfirmed. Arenaria graminifolia was found in squares ED1536, ED1378 and ED1205 of the ATPOL cartogram of $1 \times 1 \mathrm{~km}$ grid squares. The sites in the study area are shown in Figure 1 .

The paper gives information on the locations of the recorded species, its characteristics, habitat conditions, plant communities and numbers found, and threats and protection issues are discussed. Arenaria graminifolia is found in forest areas, in open pine forests, on dry ground, usually on the southern slopes of dunes with a slight slope. The plant communities belong to pine forest of the Dicrano-Pinion alliance (fresh Peucedano-Pinetum forest) or mixed fresh Querco roboris-Pinetum association. In addition to a significant share of species from the class Vaccinio-Picetea, shares of species from the classes KoelerioCorynephoretea and Nardo-Callunetea are also marked (Tab. 1).

The Arenaria graminifolia populations vary greatly in abundance, from several hundred (Biała Góra) to over three thousand vegetative shoots in the Łuże region. Generative individuals form up to 5\% of the population. The entire population of A. graminifolia in Kampinos National Park numbers 5310 shoots.

Arenaria graminifolia in Poland has been known from only 29 stations. Many of the stations recorded in the 19th and 20th centuries are historical, so it has been considered a critically endangered (CR) species (JAKUBOWSKA-GABARA 2014; KAŹMIERCZAKOWA et al. 2016). 


\section{LITERATURA}

Eliáš P., DítĚ D., Kliment J., Hrivnák R. \& FerÁková V. 2015. Red list of ferns and flowering plants of Slovakia, 5th edition (October 2014). - Biologia 70(2): 218-228.

Fischer M. A., Oswald K. \& AdLER W. 2008. Exkursionsflora für Österreich, Liechtenstein und Südtirol. Bestimmungsbuch für alle in Österreich wildwachsenden sowie die wichtigsten kultivierten Gefäßpflanzen. 3. Auflage. s. 1392. Land Oberösterreich, Biologiezentrum der Oberösterreichischen Landesmuseen, Linz.

GŁOWACKi Z. 1984. Notatki florystyczne z Mazowsza i Podlasia. - Zeszyty Naukowe Wyższej Szkoły Rolniczo-Pedagogicznej w Siedlcach, Seria Nauki Przyrodnicze 4: 51-76.

GŁowACKi Z. \& Ferchmin M. 2003. Chronione, rzadkie i zagrożone gatunki roślin naczyniowych Kampinoskiego Parku Narodowego i jego otuliny. - W: R. ANDRZEJEWSKI (red.), Kampinoski Park Narodowy. 1. Przyroda Kampinoskiego Parku Narodowego, s. 259-272. Kampinoski Park Narodowy, Izabelin.

HumięcKa T. 1980. Flora obrzeży Puszczy Kampinoskiej w okolicy Wólki Węglowej i Dąbrowy Leśnej. s. 79. Mskr. pracy magisterskiej. Wyższa Szkoła Rolniczo-Pedagogiczna w Siedlcach, Siedlce.

Jakubowska-Gabara J. 2012. Arenaria graminifolia Schrad., Piaskowiec trawiasty. - W: R. OlaczeK (red.), Czerwona księga roślin województwa łódzkiego, s. 20-21. Ogród Botaniczny w Łodzi, Uniwersytet Łódzki, Łódź.

JAKUBowska-Gabara J. 2014. Arenaria graminifolia Schrad., Piaskowiec trawiasty. - W: R. KaŹMIERCZAKOWA, K. ZARZYCKI \& Z. MireK (red.), Polska czerwona księga roślin. Paprotniki i rośliny kwiatowe. Wyd. 3, s. 114-115. Instytut Ochrony Przyrody, Polska Akademia Nauk, Kraków.

Jalas J. \& Suominen J. (red.). 1988. Atlas Florae Europaeae. Distribution of vascular plants in Europe. 3. Caryophyllaceae, 416. Cambridge University Press, Cambridge.

Kaźmierczakowa R., Bloch-OrŁowska J., Celka Z., Cwener A., Dajdok Z., Michalska-Hejduk D., Pawlikowski P., SzCZ̨ŚnIAK E. \& ZiarneK K. 2016. Polska czerwona lista paprotników i roślin kwiatowych. s. 44. Instytut Ochrony Przyrody Polskiej Akademii Nauk, Kraków.

KIRÁLY G. (red.). 2007. Vörös Lista. A magyarországi edényes flóra veszélyeztetett fajai. s. 76. Saját kiadás, Sopron.

Kobendza R. 1930. Stosunki fitosocjologiczne Puszczy Kampinoskiej. s. 201. Nakładem Towarzystwa Naukowego Warszawskiego, Warszawa.

Komsta Ł. 2016. Rewizja matematyczna siatki geobotanicznej ATPOL - propozycja algorytmów konwersji współrzędnych. - Annales Universitatis Mariae Curie-Skłodowska Sectio E Agricultura 70(1): 32-37.

Kull T., Kukk T., Leht M., Krall H., Kukk U., Kull K. \& Kuusk V. 2002. Distribution trends of rare vascular plant species in Estonia. - Biodiversity and Conservation 11: 171-196.

Matuszkiewicz W. 2013. Przewodnik do oznaczania zbiorowisk roślinnych Polski. s. 537. Wydawnictwo Naukowe PWN, Warszawa.

Meusel H., JäGER R. \& WeinerT E. 1965. Vergleichende Chronologie der zentraleuropäischen Flora. s. $583+258$ Karten. Gustaw Fischer Verlag, Jena.

OPERAT OCHRONY EKOSYSTEMÓW LEŚNYCH KPN na okres 01.01.2002 r. - 31.12.2021 r. Maszynopis. Biuro Urządzania Lasu i Geodezji Leśnej w Warszawie, Warszawa.

Plantarium: open on-line atlas and key to plants and lichens of Russia and neighbouring countries. 2007-2021. http://www.plantarium.ru/ (dostęp: 02.12.2020).

Rašomavičıus V. (red.). 2007. Red data book of Lithuania. s. 364. Publication of the Ministry of Environment of the Republic of Lithuania, Kaunas: Lutute, Vilnius. 
Senator S. A., Koneva N. V. \& Saxonov S.V. 2009. Critical flora of the Volga river basin: 1. Notes on some species of Samara oblast flora. Institute of ecology of Volga river basin, Russian Academy of Sciences. - Togliatti 11(1-2): 109-125.

SEREGIN A. 2012. Flora of Vladimir Oblast, Russia: checklist and atlas. s. 620. Grif i K., Tula.

Suslova T. A., Czhobadze A. B., Philippov D. A., Shiryaeva O. S. \& Levashov A. N. 2013. The second edition of Red Data Book of the Vologda Region: revisions in lists of protected and biological control required species of plants and fungi. - Fitoraznoobrazie Vostochnoy Evropy 7(3): 93-104.

Tuganaev V. V. (red.). 2001. Red List of the Udmurt Republic. Vascular plants, lichens and mushrooms. s. 290. Udmurtskiy Universitet, Izhevsk.

Red Data BooK of Khanty-Mansiysk autonomous county - Ugra. Animals, plants, fungi. 2nd ed. Yekaterinburg: Publishing House «Basko», 2013. 460.

Vasin A. M. (red). 2003. Red Book of the Khanty-Mansiysk Autonomous Okrug: animals, plants, fungi. s. 376. Pakrus, Ekaterinburg.

VEREY M. 2017. Teoretyczna analiza i praktyczne konsekwencje przyjęcia modelowej siatki ATPOL jako odwzorowania stożkowego definiującego konwersję współrzędnych płaskich na elipsoidę WGS 84. - Fragmenta Floristica et Geobotanica Polonica 24(2): 469-488.

ZAJĄC M. \& ZAJĄC A. 2009. Elementy geograficzne rodzimej flory Polski. s. 94. Nakładem Pracowni Chorologii Komputerowej Instytutu Botaniki Uniwersytetu Jagiellońskiego, Kraków.

KAROL TORZEWSKI (autor korespondencyjny), Katedra Ekologii, Biogeochemii i Ochrony Środowiska, Uniwersytet Wroctawski, ul. Kanonia 6/8, 50-328 Wrocław, Polska; e-mail: karol. torzewski@uwr.edu.pl

AnNA OTRĘBA, Kampinoski Park Narodowy, Gospodarstwo Szkótkarskie, ul. Polna 37, 05-084 Leszno, Polska; e-mail: aotreba@kampinoski-pn.gov.pl

Anna KęBŁowska, Kampinoski Park Narodowy, Zespót ds. Nauki i Monitoringu Przyrody, ul. Tetmajera 38,05-080 Izabelin, Polska; e-mail: akeblowska@kampinoski-pn.gov.pl

Wptynęto: 09.07.2019 r.; przyjęto do druku: 30.12.2020 r.

DOI: https://doi.org/10.35535/ffgp-2020-0042

\title{
Stellaria pallida (Caryophyllaceae) - nowe znalezisko dla flory Krakowa i skrajnie wschodnie współczesne stanowisko w Polsce
}

\author{
Stellaria pallida (Dumort.) Crép., gwiazdnica blada, (Alsine pallida Dumort.; w literaturze \\ (np. MireK i in. 2002) używana też nieważna kombinacja S. pallida (Dumort.) Piré, nom. \\ inval.; LSID: urn:Isid:ipni.org:names:983852-1) jest jednym z gatunków grupy S. media \\ (diploidalnym, 2n=22, w odróżnieniu od S. media (L.) Vill. s. str. o 2n=40-44). Od pew- \\ nego czasu (HASSLER 2020 [2018]) synonimizowana ze S. apetala Ucria; na temat sensow- \\ ności tej synonimizacji por. np. MorTon (1972), patrz też skąpa diagnoza u UCRIA (1793). \\ Ponadto, u HASSLERA (2020, „Catalogue of Life”), a prawdopodobnie za tym źródłem w wielu \\ publikacjach internetowych, użyto nieprawidłowego cytowania nazwiska autora, Bernardino \\ da Ucria: „Bernardino” zamiast „Ucria” (STAFLEU \& CowAN 1986: 562); to pierwsze używane
}

